\title{
THE ROLE OF DESTINATION MANAGEMENT ORGANIZATIONS (DMOS) IN COMMERCIALIZATION OF SUMMER TOURISM PRODUCTS: NEW CHALLENGES FOR MOUNTAIN DESTINATIONS IN AN INTEGRATED AND GLOBAL E-MARKET PLACE
}

\author{
KATARZYNA KLIMEK \\ Uniwersytet Ekonomiczny w Krakowie \\ Wydział Zarządzania, Katedra Turystyki \\ e-mail:kklimek@uek.krakow.pl
}

\begin{abstract}
\begin{tabular}{l|l} 
JEL CODES & F60, O33, Y80, Z30, Z32, Z33
\end{tabular}
KEYWORDS summer mountain tourism, Destination Management Organizations (DMOs), e-tourism market

ABSTRACT Having started to develop in the $19^{\text {th }}$ century, mountain tourism has a very strong capital attraction for international tourist flow and represents approximately $15-20 \%$ of annual global tourism income (UNEP, 2007). Despite a huge variety of activity offers in numerous mountain destinations since the mid-1960s, summer tourism, unlike winter tourism, is stagnating (France Montagne, 2014; Nydegger, 2014). However, studies concerned with summer tourism development in mountain regions are rare.

The paper presents the result of comparative study conducted between 2013, 2014 and in 2015 in 183 local and regional Destination Management Organizations (DMOs) operating in selected European and North American mountain areas in order to understand their role in the stimulation of summer tourism through various product commercialisation strategies.
\end{abstract}

\section{Introduction}

For the last several years, numerous mountain destinations in particular have been losing overnight stays during summer months due to competition from winter tourism (especially skiing), as well often from warmer, cheaper and more easily accessible beach destinations (Hallmann, Mueller\& Peters, 2015). These negative trends affect particularly mature mountain reception areas 
which suffer from lack of clear positioning, principally in the development of summer tourism (Egger, Anthamatten, 2013; Frochot, Kreziak, 2008).

Another important issue for mountain DMOs is the advent of information and communication technology (ICT) which has radically reshaped the way of creating, distributing and acquiring tourism products (Qirici, Theodhori, Elmazi, 2011). The lack of loyalty, the increasing demand for individualised holidays (often in the form of dynamic packaging) and sharing new experiences, seem to be the most important features of contemporary tourist demand (Parvaneh, Arentze, Timmermans, 2012). As Destination Management Organizations (DMOs) are important marketing and management platforms, they have to face these challenges with appropriate product diversification and commercialization strategies and adapt their distribution to the changing patterns of tourists' consumption (Buhalis, Amaranggana, 2015). Thus, it is important to understand the role of DMOs in the development of summer tourism in a highly competitive and global e-tourism market (Laesser, Bieger, Beritelli, 2007; Volgger, Pechlaner, 2014).

The fundamental objective of this paper is to present the result of comparative research conducted in 2013, 2014 and in 2015 in 183 DMOs operating in selected mature European mountain regions (i.e. the Alps, the Scandinavian Mountains) and in North America alpine resorts concerning their product development to increase the attractiveness of mountain destinations in summer.

\section{Literature review}

Mountain areas represent about $24 \%$ of world territory and about $26 \%$ of human population lives in or next to mountains and are dependent on their resources (UNEP, 2007). Summer nature-related activates constitute for the basis for the creation of mountain tourism which has been developed in most of mountain regions worldwide from the $19^{\text {th }}$ century. However, due to globalization pressure, summer mountain areas are in strong competition with often cheaper and weatherguaranteed destinations (Marrocu, Paci, 2013; Odit France, 2008; Rhône Alpes Tourisme, 2010). Moreover, for several years, the dominance of winter tourism and the decline in summer tourism is particularly observed in mature mountain destinations, e.g. The Alps, Pyrenees, and Rocky Mountains (Béchet, Margretier, 2013). In Switzerland, for example, from 2000-2012 the number of overnights generated by international tourists in the Swiss Alps decreased by $12.3 \%$, i.e. more than 20M overnight stays (Nydegger, 2014).

Another challenging task for mountain DMOs are the technological advances in information and communication technologies (ICT) which have radically changed the customers' decision process. Due to abundance of information, the number of reservations booked via internet reservation systems and via mobile applications are rapidly growing (Papathanassis, Knolle 2011; Wang, Fesenmaier, 2013). Moreover, "post-modern" tourists are becoming more demanding and quality oriented customers, seeking to co-create new experiences, especially in unpolluted and naturebased areas (Franch, Martini, Buffa, Parisi 2008).

Nevertheless, despite global warming, the perception of mountain destinations in summer is often still associated with rapidly changing weather conditions, the lack of sun and cold (Falk, 2014; 
Pröbstl-Haider, Haider, Wirth, Beardmore, 2015). Therefore, according to IPSOS survey, in 2015 more than $65 \%$ of Europeans chose beach destinations for their summer holidays, and only $20 \%$ of them spent their holidays in the mountains (IPSOS, 2016).

\section{Empirical settings \& research questions}

Overcoming seasonality to reinforce the attractiveness of mountain regions as summer destinations was the topic of the 8th edition of the World Congress on Snow and Mountain Tourism (Andorra la Vella, Andorra, 9-10 April 2014). Mountain tourism experts and DMO managers from over 40 mountain countries discussed the summer tourism issues.

During this event, short interviews were carried out with the managers of nine mountain DMOs coming from Allgäu (Germany), Andorra (Vallnord \& Granvalira resorts), Dolomiti SuperSummer (Italy), Leman sans Frontiers (France/Switzerland), Mont Tremblant \& Whistler (Canada), Tatry Mountain Resort (Slovakia), Valais (Switzerland).

The DMO managers were asked to answer two open questions:

- What kind of commercialization strategies are used in their destination to stimulate summer season?

- What are the most important factors for successful development of summer mountain tourism?

The results of the interviews, the analysis of the cases studies presented at the congress and the literature review reveal that local and regional mountain DMOs implement mainly the following two types of strategies to enhance their summer tourism:

1. The strategy of deseasonalization, i.e. the commercialization of tourist offers which are attractive all year round. (This type of strategy is currently used e.g. by: Andorra, Allgäu, Mont Tremblant in Canada (Bernhard, 2014; Mont Tremblant, 2011; Rafel, 2014).

2. The strategy of summer tourism product diversification. This type of strategic solution combines different forms of accommodation, with various thematic summer packages. This approach is currently implemented by many mountain destinations, e.g. Alpine, Scandinavian and Canadian mountain regions, (Benur, Bramwell, 2015; Nordin, Svensson, 2007, Tourism Whistler, 2014). ${ }^{1}$

Moreover, the interviewed DMO managers emphasised that sustainable use of unique natural resources, product innovation based on experience and appropriate use of ICT solutions as well as wide cooperation between tourist organisations and different stakeholder groups are three key factors to boost the summer season in mountain areas.

All those challenging issues which contemporary DMOs face have been the basis for the development of the overall study design to find answers to the following questions:

\footnotetext{
${ }^{1}$ On the basis of interviews and the best examples of summer mountain destinations presented at the 8th World Congress on Snow and Mountain Tourism, white paper in French entitled: "L'offre touristique estivale de montagne. Les exemples de bonnes pratiques de destinations touristiques" was elaborated by the author in September 2014. This report is available on: https://www.researchgate.net.
} 
- What kind of summer offer do DMOs actually sell through their websites in selected Alpine regions in Europe and in North America?

- What kind of distribution channels do selected DMOs use to commercialise their tourism products?

- Have tourism organisations implemented innovative dynamic packaging solutions?

\section{Methodology}

\section{Data collection}

The comparative analysis of summer product development in European mountains and NorthAmerican DMOs was carried out from April 2013 to October 2015. The research was based on a quantitative bottom-up approach and comprised the two following stages:

Stage 1. Benchmark study related to DMOs' on-line summer product development

On the basis of detailed criteria related to the product development and commercialization strategies of destination organisations, a comparative analysis of 183 DMO websites in eight European mountain countries (Austria, Finland, France, Germany, Italy, Norway, Sweden, Switzerland), and in selected North-American and Canadian Alpine mountain resorts was carried out.

Stage 2. Distribution channels analysis

In the second step, the study of online and offline distribution channels related to the analysis of the DMOs' commercialization strategies was conducted.

\section{Sample selection}

The sample selection was conducted on the basis of the following criteria:

- All DMOs concerned in the study were operating in mature mountain countries,

- the list of Alpine Arc DMOs (i.e. Switzerland, Austria, France, Germany and Italy) referred to the author's earlier studies carried out in those countries from 2011 to 2013 (Klimek, 2013),

- the Scandinavian and American destinations have been chosen on the basis of available online destination rankings (e.g. America's Best Mountain Resorts, Go Scandinavia),

- all selected destinations have implemented deseasonalization or diversification strategies to stimulate the tourist flow in the summer season,

- the DMOs' tourist offers were commercialised through their own websites.

In 2013 a data base of 183 mountain DMOs (63 local and 120 regional organisations) operating in selected Alpine European and North American destinations was created. The structure of the sample is presented in Figure 1. 


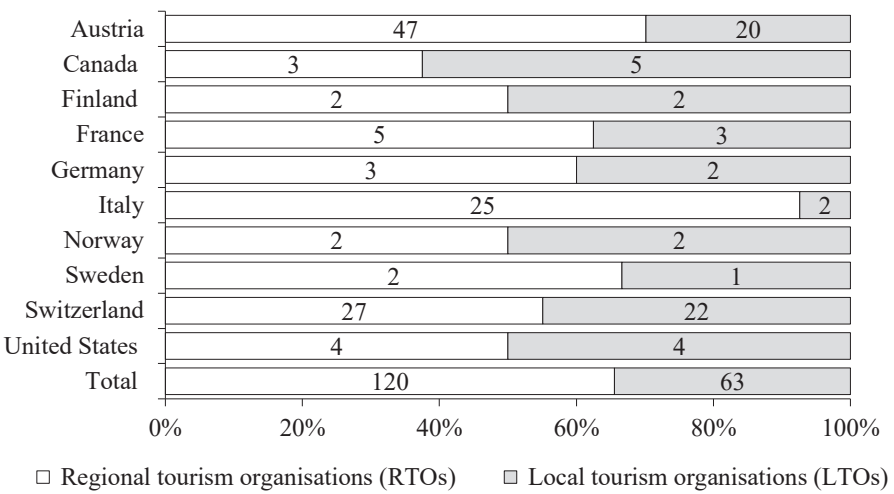

Figure 1. Characteristics of the research sample

Source: own elaboration based on research results.

\section{Discussion of findings}

Comparative analyses of $183 \mathrm{DMO}$ websites indicate the three following types of mountain summer tourist offers commercialised by those organisations:

1. Accommodation offers available in different types of lodging.

2. Pre-composed "static" packages, i.e. simple or multicomponent packages containing from two to several services and sold by destinations at a flat price.

3. Dynamic packages, i.e. the combination of different travel components, bundled and priced online and in real time.

More than $90 \%$ of analysed tourism organisations provide through their websites different types of accommodation (see Figure 2).

Most of the analysed destinations offer online bookings in different categories of hotels with board and self-catering accommodation, i.e. secondary homes and flats. The widest range of lodging is proposed by Austrian and Italian DMOs, i.e. stays in pensions, B\&Bs, farms, holiday homes, guest houses, shelters, camping grounds, etc. Many destinations in the USA, Austria, Switzerland, Sweden, Germany and Canada propose flexible stays in various forms of lodging.

In regard to the summer offers, the analysis of 583 destination proposals shows that $80 \%$ (146) of the DMOs concerned in the study commercialise a significant variety of summer packages.

Three principal types of summer packages developed by all destinations concerned in the study refer to traditional mountain activities, i.e. hiking, biking and family packages. Nevertheless, thanks to the original programming of those offers (themed holidays, 4 season health and spa\&wellness offers) as well as new facilities and introduction of summer cards (offering various discounts), certain destinations aim to better differentiate (e.g. Allgäu, Whistler, Dolomites, RhôneAlpes region, etc.). Moreover, several destinations under study (i.e. Austrian, Swiss, French, Italian and American DMOs) have developed interesting multicomponent packages based on "learning 
by doing" activities. These types of active holidays allow tourists to familiarise with a destination's "uniquities" and gain new experiences by interacting with the local population, e.g. cooking $\&$ gourmet stays, eco holidays, painting packages etc.

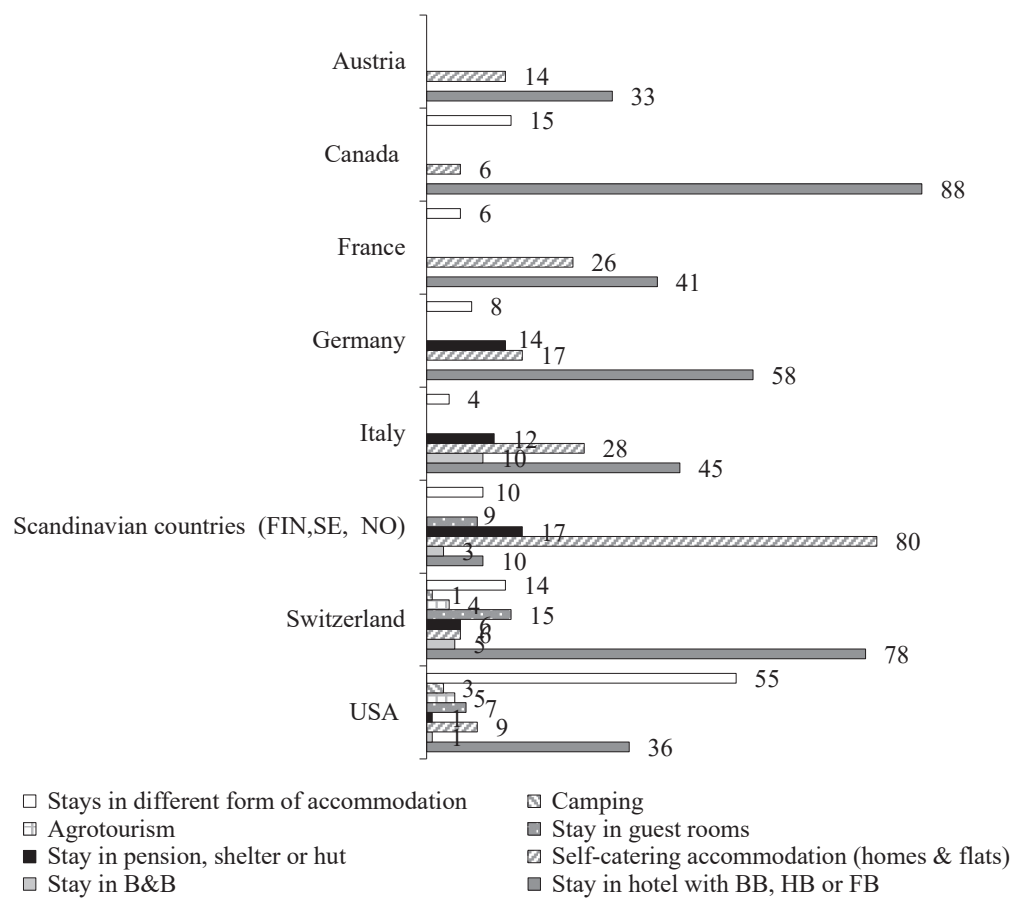

Figure 2. The types of accommodation offered for sale online by analysed 183 DMOs (\%)

Source: own elaboration based on benchmark study research results.

The DMOs under study use different distribution channels to commercialise their summer packages (see Figure 3).

In terms of online distribution channels, the most technologically advanced DMOs seem to be French, Scandinavian, North-American and Swiss ones, because the majority of their packages are commercialised on-line. In contrast, most of the Italian, German and Austrian DMOs place summer packages on their websites, but purchase is mainly possible indirectly via reservation inquiry.

The result of the benchmark study reveals also that $85 \%$ of the above-mentioned summer packages are commercialised in the form of pre-composed "static" offers, i.e. consisting of a determined number of services and sold by DMOs at a flat rate. ${ }^{2}$ Yet, as stated by Markus and Lassnig (2008) and many other authors throughout the literature review, "tailor made" packages have become fashionable and sought after by travellers. However, such innovative solutions seem to be

\footnotetext{
${ }^{2}$ The customer usually cannot change the number of services included in this kind of package.
} 
a challenging task for many, especially European DMOs concerned in the study. Indeed, among 183 analysed mountain destinations, only 27 destinations (8\% of Europeans and $81 \%$ North Americans) have implemented dynamic packages for summer season. ${ }^{3}$

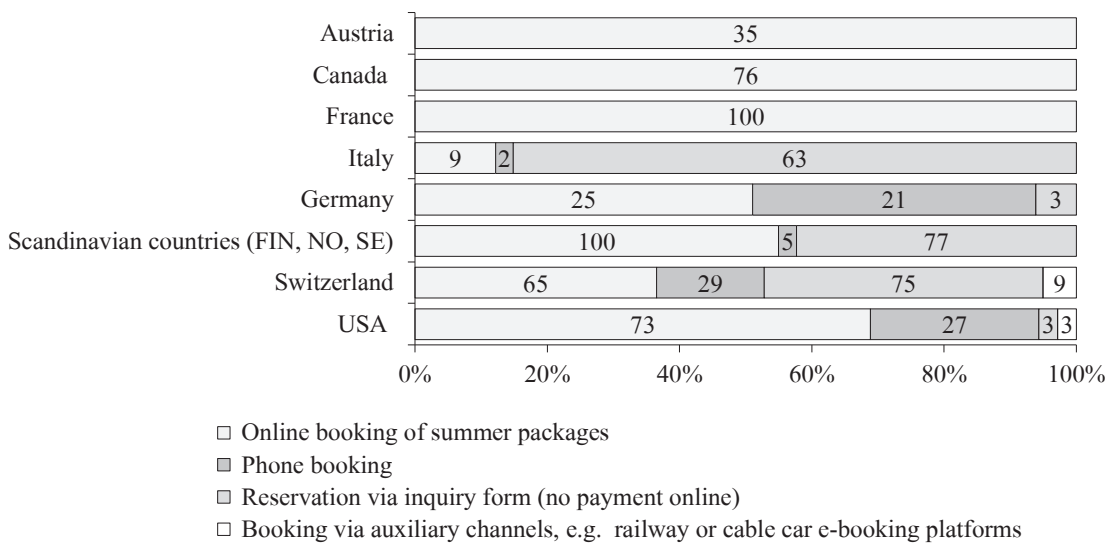

Figure 3. The structure of distribution channels used by tourist organizations for the commercialization of summer packages (\%)

Source: own elaboration based on distribution channels analysis results.

In regard to the characteristics of dynamic offers, the comparative analysis of selected destinations reveals that American and Canadian destinations seem to implement more complex dynamic solutions than other DMOs concerned in the study. During the booking process, the tourist is encouraged to dynamically select different types of summer activities, (e.g. various tourist attractions, transfers, guided tours, etc.) and add it to the chosen themed stay. Moreover, all American and Canadian DMOs concerned in the study simultaneously offer on their websites three categories of summer products, i.e. accommodation, pre-composed "static" packages and dynamic offers. The examples of dynamic themed packages and additional activities are summarised in Table 1.

In comparison to North American destinations, dynamic summer packages proposed by Alpine and Scandinavian DMOs are mostly limited to the reservation of lodging and some basic offers, i.e. ticketing, car rental, and transfers. However, the growing competition in the global e-tourism market and changing patterns of travellers' booking habits will force European mountain destinations to develop a new e-business model and to implement dynamic solutions to a greater extent (Moreno, Hörhager, Schuster, Werthner, 2015; Wozniak, Liebrich, Senn, Zemp, 2016).

${ }^{3}$ Dynamic summer mountain destinations are following: Fernie, Kicking Horse Resort, Mont Tremblant, Sun Peaks Resort, Revelstoke Mountain Resort Whistler Blackcomb (Canada), Kuopio \& Vemdalen (Finland), Obersdorf (Germany), Adelboden, Davos-Klosters, Flims-Laax-Falera, Verbier Saint-Bernard (Switzerland), Are, Levi Ski Resort, Salen (Sweden), and Alta, Utah, Deer Valley, Jackson Hole, Park City Mountain, Squaw Valley, Telluride, Vail in USA. 
Table 1. Dynamic themed package examples commercialised by selected North American destinations

\begin{tabular}{|c|c|c|}
\hline Destination & Dynamic package name & Additional activities bookable online \\
\hline \multirow{2}{*}{$\begin{array}{l}\text { Sun Peaks resort (British Columbia), } \\
\text { Canada }\end{array}$} & $\begin{array}{l}\text { Hiking Stay \& Play } \\
\text { (min. one-night stay in various types } \\
\text { of accommodation including ticket for the } \\
\text { Alpine hiking trails) }\end{array}$ & \multirow{2}{*}{$\begin{array}{l}\text { - } 4 \text { Fun Pack (includes: lift access, hiking and } \\
\text { sightseeing, sports centre day pass etc.), } \\
\text { - golf course, } \\
\text { - bungee jumping, } \\
\text { - canoe \& kayak rentals } \\
\text { - stand-up paddle lessons } \\
\text { - cross country mountain biking, } \\
\text { - horseback trail riding, } \\
\text { - airport and inter resort shuttle }\end{array}$} \\
\hline & $\begin{array}{l}\text { Bike Park Stay \& Play } \\
\text { (min. one-night stay in various types } \\
\text { of accommodation \& a Bike Park ticket) }\end{array}$ & \\
\hline Fernie, British Columbia, Canada & $\begin{array}{l}\text { Adventure Trio } \\
\text { (package offers lodging in various types } \\
\text { of hotels and three adventure summer } \\
\text { activities: golf, rafting and mountain biking) }\end{array}$ & $\begin{array}{l}\text { - aerial adventures in Fernie Aerial Park, } \\
\text { - mountain bike private lessons, } \\
\text { - ticketing \& summer passes, etc. }\end{array}$ \\
\hline \multirow{2}{*}{$\begin{array}{l}\text { Squaw Valley, Lake Tahoe, } \\
\text { California Resort, USA }\end{array}$} & $\begin{array}{l}\text { Stay and Water Play, Tahoe City } \\
\text { (min. one-night stay combined with various } \\
\text { water activities to choose) }\end{array}$ & \multirow{2}{*}{$\begin{array}{l}\text { - paddleboarding \& rafting, } \\
\text { - guided tours } \\
\text { - bike location, } \\
\text { - yoga session, } \\
\text { - golf lessons, } \\
\text { - airport transfer, etc. }\end{array}$} \\
\hline & $\begin{array}{l}\text { Fly Fishing Package } \\
\text { (stay in the hotel or in studio \& fly fishing } \\
\text { lessons for adults and children) }\end{array}$ & \\
\hline Vail, Colorado, USA & $\begin{array}{l}\text { Stay and Play Package for Red Sky Ranch } \\
\text { Golf Club } \\
\text { (min. one night stay \& golf course) }\end{array}$ & $\begin{array}{l}\text { - optional travel insurance, } \\
\text { - air travel to/from Vail } \\
\text { - public/private shuttle service, } \\
\text { - ground transportation, } \\
\text { - rental equipment }\end{array}$ \\
\hline
\end{tabular}

Source: own elaboration based on benchmark research results.

\section{Conclusions}

The results show that numerous DMOs and the mountain destinations they represent are actively involved in fighting against summer season stagnation by diversification or deseasonalisation of their summer offers. The tourism product, by its nature, is a heterogeneous and complex one, which is why it is often sold by mountain destinations in the form of integrated service packages (UNWTO, 2007). Interviews, benchmark and distribution analysis reveal that the Internet and modern ICT solutions seem to play an important role in the commercialisation of those products through the DMOs' websites. Yet, summer offers in mountain destinations are mostly developed in the form of pre-composed "static" packages. Nonetheless, the originality of those products, e.g. allowing tourists to gain and co-create new experiences, and "tailor made" dynamic packages, seem to be key issues for successful commercialisation of summer offers.

E-packaging still remains a challenging task for the majority of Alpine Arc destinations. In this context, North-American and Scandinavian DMOs can be considered a good reference point in regard to the implementation of dynamic solutions.

Due to the limited amount of study cases, the generalisation should be taken with care. The examples of product commercialisation strategies presented in the paper, may, however, constitute for an interesting benchmark for Polish local and regional tourism organizations. Indeed, it would be beneficial to create more effective product development system based on innovative, ICT solutions in the Polish mountains. 


\section{Referencencs}

Béchet, M., Margretier, J. (2013). The Future of the Alps: New markets and new products. Retrieved from: www.the-alps. eu (13.03.2017).

Benur, A.M., Bramwell, B. (2015). Tourism product development and product diversification in destinations. Tourism Management, 50, 213-224.

Bernhard, J. (2014). Alpine Wellness and Health as Four Season attraction, Case of Allgäu. Retrieved from: http://cf.cdn. unwto.org/sites/all/files/pdf/7_1_unwto_mountainlikers_2014_bernhard_joachim.pdf (16.03.2017).

Buhalis, D., Amaranggana, A. (2015). Smart Tourism Destinations: Enhancing Tourism Experience Through Personalisation of Services. In: I. Tussyadiah, A. Inversini (eds.), Information and Communication Technologies in Tourism 2015 (pp. 377-389). Springer International Publishing.

Egger, T., Anthamatten, C. (2013). Ein Road-map zur Wiederentdeckung des Alpintourismus, Bern: SAB.

France Montagne (2014). Été en montagne 2014. Dossier de presse.

Falk, M. (2014). Impact of weather conditions on tourism demand in the peak summer season over the last 50 years. Tourism Management Perspectives, 9, 24-35.

Franch, M., Martini, U., Buffa, F., Parisi, G. (2008). 4L tourism: responding to new motivations and expectations of tourists to improve the competitiveness of Alpine destinations in a sustainable way. Tourism Review, 63, 4-14.

Frochot, I., Kreziak, D. (2008). Customers' perceptions of ski resorts' images: implications for resorts' positioning strategies. Tourism and Hospitality Research, 4 (8), 298-308.

Hallmann, K., Mueller, S., Peters, M. (2015). The Assessment of Competitiveness: The Case of Three Alpine Winter Sports Destinations. Tourism Analysis, 6 (20), 677-687.

IPSOS (2016). Les Vacances d'été des Européens et des Américains. Paris.

Klimek, K. (2013). Destination Management Organizations and their shift to sustainable tourism development. European Journal of Tourism, Hospitality and Recreation, 2 (4), 27-47.

Laesser, Ch., Bieger, T., Beritelli, P. (2007). The impact of the internet on information sourcing portfolios: Insights from a mature market. Journal of Travel and Tourism Marketing, 1 (22), 63-80.

Laws, E. Richins, H. Agrusa, J., Scott, N. (2011). Tourist Destination Governance: Practice. Theory and Issues. Wallingford: UK, CABI Publishing.

Markus, M., Lassnig, M. (2008). Some Critical Remarks on Dynamic Packaging from the Perspective of SMEs and Small Tourism Destinations. In: P. O’Connor, W. Höpken, U. Gretzel (eds.), Information andCommunication Technologies in Tourism 2008. Springer International Publishing.

Marrocu, E., Paci, R. (2013). Different tourists to different destinations. Evidence from spatial interaction models. Tourism Management, 39, 71-83.

Moreno, M.D.C.C., Hörhager, G., Schuster, R., Werthner, H. (2015). Strategic e-tourism alternatives for destinations. In: I. Tussyadiah, A. Inversini (eds.), Information and Communication Technologies in Tourism 2015 (pp. 405-417). Springer International Publishing.

Mont Tremblant, Stratégie 2012-2016 et Plan d'action, Tourisme de Villégiature 4 saison. Retrieved from: http://www. creneautourismelaurentides.com (2.04.2017).

Nydegger, M. (2014). Re-inventing in summer tourism: a strategic approach at national level,

Case of Switzerland. Retrieved from: http://www.congresdeneu.ad/ponencies/2_uk.php (21.03.2017).

Nordin, S., Svensson, B. (2007). Innovative destination governance: the Swedish ski resort of Are, Entrepreneurship and Innovation, 8, 53-66.

Odit France (2008). Le tourisme estival de montagne, Paris.

Papathanassis, A., Knolle, F. (2011). Exploring the adoption and processing of online holiday reviews: A grounded theory approach. Tourism Management, 2 (32), 215-224.

Parvaneh, Z., Arentze, T., Timmermans, H. (2012). Understanding travelers' behavior in provision of travel information: A Bayesian belief approach. Procedia-Social and Behavioral Sciences, 54, 251-260. 
Pröbstl-Haider, U., Haider, W., Wirth, V., Beardmore, B. (2015). Will climate change increase the attractiveness of summer destinations in the European Alps? A survey of German tourists. Journal of Outdoor Recreation and Tourism, $11,44-57$.

Rafel, M. (2014). Deseasonalization - the Power of Innovation, the Transformation of a Parish and a Country with the Contribution of Vallnord Bike Park, Rretrieved from: http:/www.congresdeneu.ad/ponencies/11.php (2.04.2017).

Rhône Alpes Tourisme. (2010). Montagne été. Des clés pour réenchanter la destination auprès des clients potentielles. Rhône Alpes.

Tourism Whistler (2014). Tourism Whistler 2013. Annual Report. Whistler.

Qirici, E., Theodhori, O, Elmazi, L. (2011). E-Marketing and ICT-Supported tourist destination management. Implications for tourism industry in global recession. International Journal of Management Cases, 3 (13), 152-158.

UNEP (2007). Tourism and Mountains. A Practical Guide to Managing the Environmental and Social Impacts of Mountain Tours. Paris.

UNWTO (2007). A Practical Guide to Tourism Destination Management. Madrid.

Volgger, M., Pechlaner, H. (2014). Requirements for destination management organizations in destination governance: Understanding DMO success. Tourism Management, 41, 64-75.

Wang, D., Fesenmaier, D.R. (2013). Transforming the travel experience: The use of smartphones for travel. In: L. Cantoni, Z. Xiang (eds.), Information and Communication Technologies in Tourism 2013 (pp. 58-69). Springer International Publishing.

Wozniak, T., Liebrich, A., Senn, Y., Zemp, M. (2016). Alpine Tourists' Willingness to Engage in Virtual Co-Creation of Experiences. In: A. Inversini, R. Schegg (eds.), Information and Communication Technologies in Tourism 2016 (pp. 281-294). Springer International Publishing.

\section{ROLA ORGANIZACJI TURYSTYCZNYCH DMOS W KOMERCJALIZACJI LETNICH PRODUKTÓW TURYSTYCZNYCH. NOWE WYZWANIA DLA DESTYNACJI GÓRSKICH NA ZINTEGROWANYM I GLOBALNYM E-RYNKU TURYSTYCZNYM}

SŁOWA KLUCZOWE STRESZCZENIE letnia turystyka górska, organizacje turystyczne (DMOs), e-turystyka

Od II połowy XIX wieku turystyka górska przyczynia się do rozwoju międzynarodowego ruchu turystycznego i według szacunków corocznie generuje około 15-20\% przychodów osiąganych z turystyki na świecie (UNEP, 2007). Pomimo ogromnej różnorodności ofert, od połowy lat 60 . XX wieku, w wielu regionach górskich, zauważalna jest stagnacja turystyki letniej, w przeciwieństwie do dobrze rozwiniętej turystyki zimowej (France Montagne, 2014; Nydegger, 2014). Badania dotyczące rozwoju letniej turystyki w regionach górskich są jednak rzadko prezentowane w opracowaniach naukowych w Polsce i za granicą. Celem niniejszego artykułu jest ukazanie roli lokalnych i regionalnych organizacji turystycznych (DMOs) w stymulowaniu letniej turystyki górskiej za pośrednictwem zdywersyfikowanych strategii produktowych. W artykule zaprezentowano wyniki badań porównawczych przeprowadzonych w latach 2013, 2014 i 2015 w 183 lokalnych i regionalnych organizacjach turystycznych działających w wybranych europejskich oraz północnoamerykańskich destynacjach górskich. 